\section{THURSDAY, FEBRUARY 20, 1872}

\section{THE COAL MINE COMMISSION}

$\mathrm{M}$ UCH misapprehension of facts, and much ignorance of scientific principles are, it is to be feared, the most prominent characteristics of the knowledge possessed by most people regarding the nature and mode of occurrence of colliery explosions. Pompous platitudes about the carelessness of the men, and windy panegyrics on the virtues of the safety-lamp have been freely pronounced times without number during the last two generations of mankind. Committees on accidents in mines have met, discussed the question, and separated; inspectors of mines have been appointed, stringent regulations have been framed and enforced which bind both employer and employed, the public have listened to the tale of woe, have wept over the fate of the hapless miner, and have subscribed hundreds of thousands of pounds in aid of his widows and orphans, and yet with all this, and more untold, the history of the past eighteen months would seem almost to indicate that we are as far as ever from a true solution of this much-agitated question.

Can science, then, do nothing? is her hand unable to save even a moiety of the lives that are being constantly cast away before her very eyes? To this question, which is very often asked, the reply is simple. Science can undoubtedly solve the question, but she must do it in her own way; she must approach it with the sap and mine of investigation and research; she must have her own time to do it, and above all, she requires to be encouraged. Scientific men have, no doubt, sometimes turned their attention to the subject without much apparent rèsult, but their efforts have, as a rule, been of short duration, and they have too often met with discouragement, active opposition, and incredulity. We have only to point to Dr. Birbeck's letter to the South Shields Committee (I 843 ) at p. 48 of their report, and to the report addressed to the committee of the coal trade by the special committee appointed to take into consideration the report of Lyell and Faraday on the Haswell Colliery explosion to exemplify what we mean. We wish we could say that there are no examples of the same kind at the present day, but unfortunately we are unable to do so.

Putting aside these gloomy thoughts, however, we are rejoiced to see science so well represented on the Commission just appointed to inquire into and report upon this matter. We had always imagined it to be a purely scientific question, having almost no relation to the art of mining in its stricter sense. We confess that ours is not the common view, but that, on the contrary, it is usually supposed that if practical men, including inspectors of mines, are unable to prevent explosions, nobody else need try to do so. We cannot accede to such a proposition; nay, more, we protest against it. If disasters of this kind could be stopped by hedging round the collier and his employer with an impenetrable palisade of instructions and restrictions, then we are bound to acknowledge that the practical man with a legal turn of mind could do it effectually. This method has been tried, however, or rather, it is now in force, and we see its results.

The new Commissioners will, no doubt, seek to acquaint themselves to some extent with the work of their predecessors and contemporaries; they will also weigh carefully the opinions that will be expressed before them, and take account more of the facts and reasoning that can be adduced in support of such opinions than of the age and position of those who express them. For example, they will not come to any conclusion regarding the influence of fluctuations of atmospheric pressure and temperature upon the issue of fire-damp from coal until they have obtained a sufficiently large and well-authenticated mass of information to enable them to arrive at sound conclusions. The data which have been collected and tabulated by Messrs. Scott and Galloway and others are amply sufficient to show that the matter is worthy of further careful consideration, but they do not extend over a lengthened period of time, and we venture to say that their weight would be greatly augmented by a further addition of similar facts. As to the use of fire-damp indicators (and by this we suppose are meant instruments for giving notice of the occurrence of outbursts of gas), we fear that their importance has been absurdly exaggerated and that they are brought forward by those who know nothing about mining. It will be for the Commissioners to inquire, however, whether there are any mines in existence in which they could really be of any service. The systematic observation of the air in mines may be taken, we suppose, to apply both as to its quality and quantity. As regards its quality, it will have to be determined whether observations of the height of the cap on the lamp-flame reduced to small dimensions, such as those described by Mr. Galloway in the Proceedings of the Royal Societ $y$, i 876 , are sufficiently accurate and reliable, or whether it will be necessary or expedient to bring into use some kind of instrument iike the grisoumetre, by means of which a rapid analysis of the air can be made. As regards its quantity, on the other hand, it may be suggested that if the velocity and drag of the currents could be continuously recorded in a manner similar to the pressure and temperature of the air at the meteorological stations, a check might be kept upon the ventilation, and changes in its efficiency could be ascertained by a mere inspection of the curres. Improved methods of rentilation and illumination are important objects. Powerful machines are now being erected at most new collieries, but these alone cannot prevent explosions, if we may judge by the case of Abercarne, which was thoroughly well equipped in that respect. The Commissioners must beware of being drawn into the belief that some advantage can be gained by forcing the air into the mines instead of driving it out by way of keeping the gas in the coal, as it were, and thereby escaping the effect of atmospheric influences. They themselves will be able to balance the slight gain of pressure that could be obtained in this way with the normal pressure of gas in the coal. It will be well worth their while, however, to consider the means that have been suggested of late years for producing an artificial barometric depression in the workings with the view of extracting the gas from the open fissures, old works, and even to some extent from the face of the coal, when the men are out of the mine, and then sweeping it out by admitting air freely through the downcast shaft, and at the same time continuing to work the 
exhausting machine. As to ourselves, we thought the idea chimerical when it was first brought under our notice; but after reading a pamphlet on the subject by M. Francis Laur, of Saint-Etienne, we were forced to change our mind. The kind of safety-lamps that ought to be employed will form a subject of warm debate, but we can confidently assure the Commission that if they separate without recommending the universal adoption of lamps that will not continue to burn in an explosive atmosphere, and of more perfect locks than the present ones, they will have failed to satisfy one of the most important requirements of the time. We say this without prejudice to the means that may be thought best for examining the workings for accumulations of gas : we refer to the lamps supplied to the common workmen. The employment of explosive agents in getting the mineral, and other particulars relating to mines and mining operations include, we think, the most important of all the questions that will come before the Commissioners. What is coal-dust? and what bearing has it on the subject? If the presence of coal-dust is, after all, the cause of all these great explosions, and if, as has been once before asserted in these pages, great explosions never happen in damp or wet mines, but always in dry ones containing coal-dust, then surely the Commissioners would be but dallying with the subject if they omitted to carefully weigh all the facts that have been adduced in favour of this hypothesis. They will have to turn to other sources, however, than the reports of the inspectors of mines for information; and they might do worse than consult the report drawn out by $M$. Haton de la Goupillière of the doings of a similar commission appointed by the French Government in 1878, under the title of Rôle des Poussières de Charbon, in which they will find it alluded to, and an historical account given of the steps that have led to our present knowledge regarding it. Otherwise the literature of our own country is not quite so sterile in this respect as it was three years ago; but doubtless the Commissioners will provide themselves with all the most recent information.

The dangers due to the use of explosives in mines are of three kinds : firstly, the shot may ignite an accumulation of gas directly; secondly, it may effect the same thing indirectly by driving the flame of a safety-lamp burning in the accumulation through the meshes of its wire gauze cylinder; thirdly; the sudden rush of flame and the violent disturbance of the air caused by a blownout shot (that is to say, one which expels its tamping without bringing down or even breaking the rock) may raise and ignite the coal-dust in front of it, and more especially if it is directed towards "or parallel with and near to the floor. In the last case the flame has been often known to extend to a distance of thirty, forty, and even eighty yards from its origin, and such a disturbance faking place under favourable conditions is quite sufficient to initiate explosions such as those of Blantyre, Haydock, Abercarne, and Dinas, in which close upon a thousand lives have been lost within the last eighteen months. When we add that each of these mines was very dry and contained plenty" of coal-dust, and was not known to contain more than insignificant accumulations of firedamp, quite insufficient to account for a tithe of the extent and violence of the explosions, we have said enough, we think, to make it apparent how pressing is this matter.

Blasting operations can be safely carried out in any mine if the shots are not fired near explosive accumulations, if the lamps are of such a construction that they cannot burn in an explosive atmosphere, and if the mine is a damp one. It is easy enough to provide the two first requirements, and it is obvious that by plentifully watering the roadways we can turn a naturally dry mine into a damp one and avoid danger such as we have described from blasting, as well as localise explosions of fire-damp. We have seen it stated in a footnote at p. $66 \mathrm{I}$ of the last number of the Bulletin de la Société de l'Industrie Minérale that dusty mines, which are at the same time well ventilated, may be watered frequently without obtaining permanent humidity. Fortunately, however, we are in a position to point to an example which has come under our own immediate notice, of an extensive mine in which the workings are kept damp throughout their whole extent by a constant application of water. In the case to which we refer the daily output of coal is 800 tons, the temperature of the workings is between $70^{\circ}$ and $80^{\circ} \mathrm{Fahr}$., and the amount of air passing into and out of the mine is between 80,000 and 90,000 cubic feet per minute.

In conclusion we are eminently satisfied that science is so well represented on the Commission; and if its various members will pull together like a well-balanced team, we anticipate the happiest results from its researches and labours.

\section{KINGZETT'S ANIMAL CHEMISTRY}

Animal Chemistry; or, The Relations of Chemistry to Physiology and Pathology. A Manual for Medical Men and Scientific Chemists. By. Charles Thomas Kingzett, F.C.S. (London: Longmans, Green, and Co.)

FOR many years the want of a good manual of physiological chemistry or animal chemistry in the English language has been a standing reproach to English science. The causes of this want are not far to seek. Physiology has not many votaries in England, and physiological chemistry, being in interest one step farther than physiology from the verge of medical practice, has still fewer followers. The number of possible writers of a text-book of animal chemistry has, therefore, been small; and, among them, the number of men whose capability and opportunities for such an undertaking might justly have led them to hope for a successful issue to their labours has, it is needless to say, been smaller still. The qualifications to be looked for in one who attempts the task of writing such a manual are indeed not slight. He must be a thoroughly trained chemist whose judgment has been much exercised in the appreciation of chemical questions; be must be a physiologist with a sound and direct knowledge of most of the practical methods of physiology; he must be an anatomist who is fairly well acquainted with the microscopic structure of animal tissues; and he should have some insight, exact if not special, into morbid processes and pathological states. We need not wonder, then, that the labourers have been few. 